\title{
Immunomodulatory Effects of Nigella sativa Extract on Chicken Peripheral Blood Mononuclear Cells: In-vitro
}

\author{
Yogendra Singh ${ }^{1,2}$, Patel Nikunjkumar Prakashbhai ${ }^{1}$, Beenam Saxena ${ }^{2}$ and Saravanan Ramakrishnan ${ }^{1 *}$ \\ ${ }^{1}$ Avian Immunology laboratory, Immunology Section, ICAR - Indian Veterinary Research Institute, Izatnagar, Bareilly, \\ Uttar Pradesh, INDIA \\ ${ }^{2}$ Department of Zoology, Bareilly College, Bareilly, Uttar Pradesh, INDIA \\ "Corresponding author: R Saravanan; E-mail: dearsaromib@yahoo.com
}

Received: 07 July, 2021

Revised: 13 July, 2021

Accepted: 18 July, 2021

\begin{abstract}
Nigella sativa has been used since ancient time for curing various infectious diseases due to its miraculous biochemical and pharmacological properties. It belongs to the Ranunculaceae family and generally used as food additives and also known as black cumin. The active components in black cumin have shown remarkable characteristics like antimicrobial, anti-diabetics, anti-cancerous, anti-tumoral, analgesic, anti-fungal, anti-inflammatory, and immunological and immune-potentiating effects. In the present study, we investigated the immunomodulatory effect of Nigella sativa seeds extract on the chicken peripheral blood mononuclear cells (PBMCs). The chicken PBMCs were stimulated with two different doses (125 $\mu \mathrm{g} / \mathrm{ml} ; 250 \mu \mathrm{g} / \mathrm{ml})$ of Nigella sativa seeds extract and the cells were harvested at different time points till $48 \mathrm{~h}$ post-stimulation for analysis of various immune gene expression by quantitative real-time PCR. High dose $(250 \mu \mathrm{g} / \mathrm{ml})$ of Nigella sativa seed extract showed remarkable induction of immune response genes (IL-1 $\beta$, IFN- $\beta$, IFN- $\gamma$, IL-4, IL-10, IL-13, IL-12 transcripts) expression at 48h post-stimulation. The results indicated the immunomodulatory activity of the Nigella sativa seed extract on the chicken PBMCs and suggested the potential use as an adjuvant with various vaccines in chicken.
\end{abstract}

\section{HIGHLIGHTS}

0 Immunomodulatory effect of Nigella sativa extract was observed in chicken PBMCs.

( Nigella sativa seed extract enhanced expression of immune response genes in chicken PBMCs.

Keywords: Nigella sativa, PBMCs, immunomodulator, immune response genes, chicken

Natural products that are used traditionally will help in the rediscovery of useful drugs. Herbal products are widely used in the treatment of various human diseases for centuries. Nigella sativa is a very popular plant from Ranunculaceae family with medicinal values. Nigella sativa have been broadly used as liver tonic, antidiarrheal, antifungal, antibacterial and also used in the cure of skin disorders. Many researchers confirmed its wide pharmacological actions that includes: anti-diabetic, anti-bacterial, antiviral, antioxidant, anti-malarial (Okeola et al., 2011), anti-inflammatory, anticancer (Dilshad et al., 2012) and gastro-protective (Bukar et al., 2017). The therapeutic properties of Nigella sativa seed oil are due to the presence of a bioactive component thymoquinone
(Ahmad et al., 2013). Treatment of Nigella sativa to the sensitized guinea pigs significantly reduced pathological changes in lungs and increased level of IFN- $\gamma$ (Boskabady et al., 2011). It has been also observed that seed oil and extract of Nigella sativa reduce the viability of human lung cancer cells (Al-Sheddi et al., 2014). In Islamic literature Nigella sativa is mentioned as a miracle plant because it is a very effective herbal remedy for many diseases (Hussain and Hussain, 2016). Recently, antibacterial activity of

How to cite this article: Singh, Y., Prakashbhai, P.N., Saxena, B. and Ramakrishnan, S. (2021). Immunomodulatory Effects of Nigella sativa Extract on Chicken Peripheral Blood Mononuclear Cells: In-vitro. J. Anim. Res., 11(04): 579-586.

Source of Support: None; Conflict of Interest: None क 
Nigella sativa has been observed against multidrug resistance strains of Staphylococcus aureus (Salman and Khan, 2016). The extract of Nigella sativa was used by many workers as an immunomodulating agent. Recent research reveals that increment in dose of ethanolic extract of Nigella sativa significantly reduced the levels of TNF $\alpha$ in mice pre-eclampsia model (Zainiyah et al., 2018). Further, ethanol extract of Nigella sativa showed excessive antioxidant activity and also observed rich in antioxidants together with gallic acid, eucalyptol and levomenthol that play very imperative function in the enhancement of hepato-renal health in rats (Akinwumi et al., 2020). Nigella sativa play an important role in balancing the Th1/ Th2 cytokines production and asthma control in asthmatic children (Barlianto et al., 2017). There is a requirement of studies to shed more light on the immunomodulatory effects of Nigella sativa on Th1/Th2 cytokine by using different model in both in vitro and in vivo conditions. Th1 cytokines mediates cell mediated immune response, whereas Th2 cytokines play important role in humoral immunity and regulate allergic inflammatory response. The effect of Nigella sativa extract on chicken immune system is not yet explored. This knowledge would help in understanding the mode of action and molecular mechanisms involved in the immunomodulatory activities of Nigella sativa extract in the chicken model. Hence, we aimed to explore the immunomodulatory activity of purified extract from Nigella sativa seeds on chicken PBMCs.

\section{MATERIALS AND METHODS}

\section{Reagents}

RPMI 1640 with L-glutamine and 25 mM HEPES buffer were purchased from HiMedia Pvt. Ltd. India. Fetal bovine serum was bought from Hyclone (Logan, USA) and heat inactivated at $56^{\circ} \mathrm{C}$ for $30 \mathrm{~min}$.

\section{Extract preparation}

Seeds of Nigella sativa were purchased from authenticated herb store available at Bareilly, UP. India. The seeds were dried at $45{ }^{\circ} \mathrm{C}$ and powdered. Ten grams of powdered seed was stirred overnight in $70 \%$ methanol $(100 \mathrm{ml})$, centrifuged at $10,000 \mathrm{rpm}$ at $4{ }^{\circ} \mathrm{C}$ for $10 \mathrm{~min}$, and the supernatant was collected. Methanol was removed by evaporation, and the yield was $12 \%(\mathrm{w} / \mathrm{w})$. The seed extract was suspended in DMSO for in vitro studies. The extract was sterilized by filtration using $0.22 \mu \mathrm{m}$ syringe filters and stored at $-20{ }^{\circ} \mathrm{C}$ till use.

\section{Primers}

Published oligonucleotide primers specific to chicken genes viz., GAPDH, IL- $1 \beta$, IFN- $\beta$, IFN- $\gamma$, IL-4, IL-10, IL-12, IL-13 were synthesized from M/S Integrated DNA Technologies, Iowa, USA and used in the study (Table 1).

\section{Chicken peripheral blood mononuclear cells (PBMCs) isolation}

Blood was collected with heparin (20 IU/ml of blood) from the experimental birds $(n=6)$ maintained in the Avian Immunology laboratory, Immunology Section, ICAR-IVRI, Izatnagar. The blood was layered on to the equal amount of Ficoll Hypaque (Sigma, MO, USA) with specific gravity $1.077 \mathrm{~g} / \mathrm{ml}$ and PBMCs were isoloated by density gradient centrifugation at $500 \times \mathrm{g}$ for $45 \mathrm{~min}$. The PBMCs were washed twice with sterile PBS (pH 7.2) and the cells were re-suspended in RPMI-1640 medium containing $2 \%$ fetal bovine serum. The viability of cells was determined by trypan blue dye exclusion method and cells were adjusted to a concentration of $1 \times 10^{7}$ cells $/ \mathrm{ml}$ and stored on ice.

\section{Determination of the in vitro Cytotoxic activity of Nigella sativa to chicken PBMCs}

The PBMCs $\left(1 \times 10^{6}\right.$ cells $)$ were incubated with various concentrations of Nigella sativa extract for $48 \mathrm{~h}$ at 40 ${ }^{\circ} \mathrm{C}, 5 \% \mathrm{CO}_{2}$ environment with cells containing medium alone as the negative control. Twenty microlitre of MTT ( $5 \mathrm{mg} / \mathrm{ml}$ ) was added (Cole, 1986; Campling et al., 1991) and further incubated in the same condition for $4 \mathrm{~h}$. The absorbance value was recorded at $570 \mathrm{~nm}$ and the level of cytotoxicity was assessed by the following formula:

Stimulation index $=$ OD of the stimulated cells with the extract/OD of the unstimulated cells 
Table 1: Primers used for quantitative real time PCR

\begin{tabular}{|c|c|c|c|}
\hline Target Gene & Primer sequence (5'-3') & Product size (bp) & Reference \\
\hline \multirow[t]{2}{*}{ GAPDH } & F: AGCACCCGCATCAAAGG & 283 & \multirow{2}{*}{ Kuo et al., 2017} \\
\hline & R: CATCATCCCAGCGTCCA & & \\
\hline \multirow[t]{2}{*}{ IL-1 $\beta$} & F: GGATTCTGAGCACACCACAGT & 272 & \multirow{2}{*}{ Ramakrishnan et al., 2015} \\
\hline & R: TCTGGTTGATGTCGAAGATGTC & & \\
\hline \multirow[t]{2}{*}{ IFN- $\beta$} & F: GCTCACCTCAGCATCAACAA & 187 & \multirow{2}{*}{ Ramakrishnan et al., 2015} \\
\hline & R: GGGTGTTGAGACGTTTGGAT & & \\
\hline \multirow[t]{2}{*}{ IFN- $\gamma$} & F: TGAGCCAGATTGTTTCGATG & 152 & \multirow{2}{*}{ Ramakrishnan et al., 2015} \\
\hline & R: CTTGGCCAGGTCCATGATA & & \\
\hline \multirow[t]{2}{*}{ IL-4 } & F: GTGCCCACGCTGTGCTTAC & 82 & \multirow{2}{*}{ Huang et al., 2019} \\
\hline & R: AGGAAACCTCTCCCTGGATGTC & & \\
\hline \multirow[t]{2}{*}{ IL-10 } & F: CGCTGTCACCGCTTCTTCA & 88 & \multirow{2}{*}{ Zhang et al., 2019} \\
\hline & R: TCCCGTTCTCATCCATCTTCTC & & \\
\hline \multirow[t]{2}{*}{$1 \mathrm{~L}-12$} & F:CGAAGTGAAGGAGTTCCCAGAT & 123 & \multirow{2}{*}{ Liu et al., 2010} \\
\hline & R: GACCGTATCATTTGCCCATTG & & \\
\hline \multirow[t]{2}{*}{ IL-13 } & F:GCTGAGGGTGAAGTTTGAGGAA & 123 & \multirow{2}{*}{ Liu et al., 2010} \\
\hline & R: GAAGCGCAGCATCTCTGACA & & \\
\hline
\end{tabular}

\section{Stimulation of chicken PBMCs with Nigella sativa extract}

The PBMCs $\left(1 \times 10^{6}\right.$ cells $)$ were stimulated with two different doses of (low dose, $125 \mu \mathrm{g} / \mathrm{ml}$; high dose, $250 \mu \mathrm{g}$ / $\mathrm{ml}$ ) of Nigella sativa seed extract (Swamy and Tan, 2000 and Gholamnezhad, et al., 2015) by incubation at $40^{\circ} \mathrm{C}$, $5 \% \mathrm{CO}_{2}$ environment. Then, the cells were harvested at $0,3,6,12,24$ and $48 \mathrm{~h}$ post-stimulation for the evalution of immune response genes by quantitative real-time PCR.

\section{Isolation of total RNA from PBMCs}

Treated and untreated PBMCs were centrifuged for 5 min and supernatant was discarded. Into the pellet 750 $\mu 1$ of QIAzol lysis reagent (Qiagen, CA, USA) and 250 $\mu 1$ of chloroform were added and vortexed for $30 \mathrm{~s}$. For separation of phases, the tubes were centrifuged at 12000 $\times \mathrm{g}$ for $20 \mathrm{~min}$ at $4^{\circ} \mathrm{C}$. The supernatant aqueous phase rich in RNA was precipitated with $400 \mu \mathrm{l}$ of isopropanol at $12000 \times \mathrm{g}$ for $15 \mathrm{~min}$ and washed with $1 \mathrm{ml}$ of $70 \%$ ethanol. Then, the tubes were air dried by inverting on to the clean filter paper for about $10 \mathrm{~min}$ for the removal of excess ethanol. The RNA pellet was dissolved in nuclease free water $(20 \mu 1)$. The purity of RNA was checked by measuring the absorbance at 260 and $280 \mathrm{~nm}$ in a Nanodrop UV spectrophotometer (Thermo Scientific, USA).

\section{Preparation of complementary DNA (cDNA)}

For preparation of cDNA, total RNA $(2 \mu \mathrm{g})$ was taken by using Revertaid ${ }^{\mathrm{TM}}$ First Strand cDNA Synthesis Kit (Thermo Scientific, USA) following the manufacturer's instructions. For the synthesis of cDNA, two $\mu \mathrm{g}$ of RNA and $1 \mu \mathrm{L}$ of random hexamer (Thermo Scientific, USA) were added to the $9.5 \mu \mathrm{L}$ of nuclease-free water (total 12.5 $\mu \mathrm{L}$ volume) and incubated at $65{ }^{\circ} \mathrm{C}$ for $10 \mathrm{~min}$. Further, following reagents were added to the tubes: $5 \mathrm{X}$ reaction buffer $(4 \mu \mathrm{L})$, Ribolock RNase inhibitor $(0.5 \mu \mathrm{L}), 10 \mathrm{mM}$ dNTP mix $(2 \mu \mathrm{L})$, and Revert Aid reverse transcriptase $(1 \mu \mathrm{L})$ and mixed and then incubated at $25^{\circ} \mathrm{C}$ for $10 \mathrm{~min}$ accompanied by $50{ }^{\circ} \mathrm{C}$ for $50 \mathrm{~min}$ for cDNA synthesis and the reaction was terminated by heating at $85^{\circ} \mathrm{C}$ for $5 \mathrm{~min}$. cDNA was stored at $-20{ }^{\circ} \mathrm{C}$.

\section{Quantitative Real-Time PCR (qPCR)}

Differential expression of immune response genes such as IL- $1 \beta$, IFN- $\beta$, IFN- $\gamma$, IL-4, IL-13, IL-10 IL-12 were 
analyzed by real-time PCR (Agilent Technologies AriaMx Real- Time PCR System). The chicken specific primers (Table 1) were used. The qPCR mixture consisted of 2 $\mu 1$ cDNA, $10 \mu l$ of QuantiFast ${ }^{\circledR}$ SYBR Green Master Mix (Qiagen, CA, USA), primers $(0.5 \mu \mathrm{l}$ each, $10 \mathrm{pmol}$ concentration) and RNase free water to a volume of 20 $\mu 1$. Real time PCR was carried out by using the following programme: 1 cycle at $95{ }^{\circ} \mathrm{C}$ for $5 \mathrm{~min}$, followed by 40 cycles each of $94{ }^{\circ} \mathrm{C}$ for $30 \mathrm{sec}, 60{ }^{\circ} \mathrm{C}$ for $45 \mathrm{sec}, 70^{\circ} \mathrm{C}$ for $45 \mathrm{sec}$ and 1 cycle of $94{ }^{\circ} \mathrm{C}$ for $30 \mathrm{sec}$. To determine the specificity of amplicon melting curve was carried out as the final step. All the samples including treated and controls were carried out in duplicates. Expression levels of IL- $1 \beta$, IFN- $\beta$, IFN- $\gamma$, IL-4, IL-13, IL-10 and IL-12 transcripts were calculated relative to the expression of the GAPDH gene (Boeglin et al., 2011; Berzi et al., 2014) and mentioned as $n$-fold increase or decrease relative to the control samples (Pfaffl, 2001). The Ct (cyclic threshold) value was recorded as the cycle in which reporter dye concentration crossed a preset threshold. The data of real time PCR were analyzed by $2^{-\Delta \Delta \mathrm{Ct}}$ method (Pfaffl, 2001) to derive the relative fold change in mRNA of the target gene.

\section{Statistical analysis}

The relative fold change in the expression of immune response genes were analyzed by using analysis of variance (ANOVA) one way; when the F ratio was significant, least significant difference (LSD) was used as post hoc test. * $(\mathrm{P} \leq 0.05)$ and ${ }^{* *}(\mathrm{P} \leq 0.01)$ indicate statistically significant. GraphPad Prism 8.0 was used for the statistical analyses.

\section{RESULTS AND DISCUSSION}

\section{Effect of Nigella sativa seed extract on pro-inflammatory cytokine expression in the chicken PBMCs}

IL- $1 \beta$ belongs to the $\beta$-trefoil family of cytokines. The role of IL-1 $\beta$ in the chicken's immune response to disease will result in a pro-inflammatory response. IL-1 $\beta$ is expressed as a propeptide, subsequently cleaved by the action of caspase- 1 in a position near a conserved aspartic acid residue in viral infection, IL-1 activity was increased in macrophage supernatants from birds suffering from poultry enteritis and mortality syndrome (Heggen et al.,
2000). IL-1 $\beta$ mRNA levels, of course, do not necessarily correspond to an effective release of biologically active protein. There were significantly $(P \leq 1.01)$ higher IL-1 $\beta$ transcripts in the PBMCs treated with high dose of Nigella sativa extract at 12, 24 and $48 \mathrm{~h}$ post-stimulation, which were $7.3932 \pm 2.01284,9.9547 \pm 2.14836$ and 17.4484 \pm 3.16608 folds, respectively (Fig. 1). However, there was no significant expression of IL- $1 \beta$ transcripts in the PBMCs treated with the low dose of the extract. The results showed that the Nigella sativa extract has the potential to stimulate inflammatory responses in the chicken PBMCs.

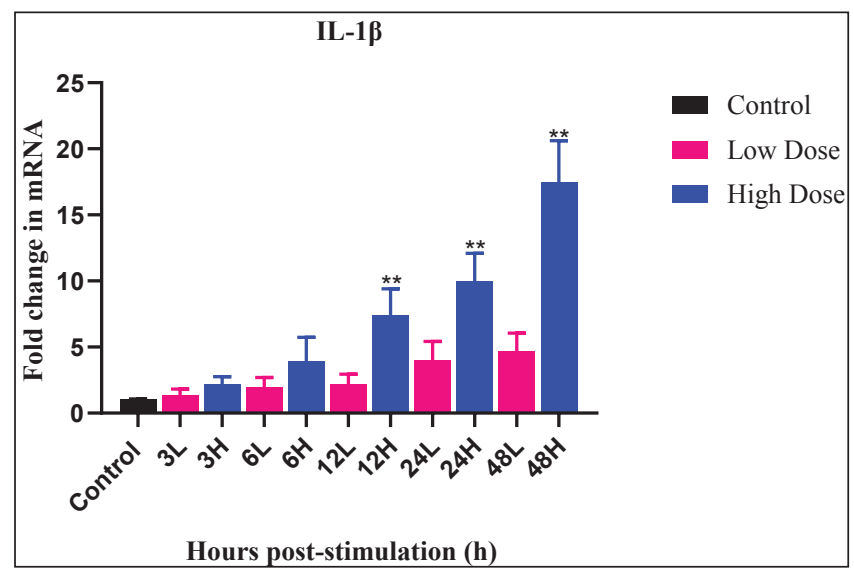

Fig. 1: Relative expression of IL-1 $\beta$ transcript in PBMCs stimulated with Low dose $(125 \mu \mathrm{g} / \mathrm{ml})$ and High dose $(250 \mu \mathrm{g} /$ $\mathrm{ml}$ ) of Nigella sativa seed extract over a period of $48 \mathrm{~h}$

\section{Effect of Nigella sativa seed extract on antiviral gene expression in the chicken PBMCs}

Interferons (IFN) are characterized by antiviral properties. Macrophages, monocytes, T cells, B cells and NK cells are predominant producer of type I IFNs which in turn activates IFN stimulatory genes (Seo and Hahm, 2010). IFN- $\alpha$ and IFN- $\beta$ have antiviral activity and type I IFNs generally induce DC maturation that effectively enhance the adaptive immunity (Rahman and Eo, 2012). The present findings showed significantly $(P \leq 0.01)$ higher IFN- $\beta$ transcripts in the chicken PBMCs when stimulated with high dose of Nigella sativa extract at 24 and $48 \mathrm{~h}$ post-stimulation, which were $10.0688 \pm 2.59787$ and $18.3659 \pm 2.83$ folds, respectively (Fig. 2). Further, the results indicated the ability of Nigella sativa extract to stimulate the type I IFN in the chicken PBMCs. 


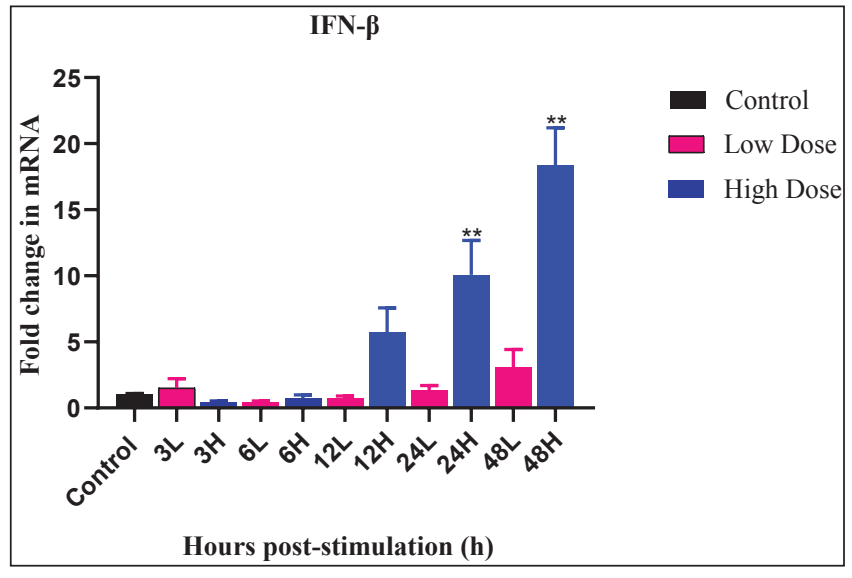

Fig. 2: Relative expression of IFN- $\beta$ transcript in chicken PBMCs stimulated with Low dose $(125 \mu \mathrm{g} / \mathrm{ml})$ and High dose $(250 \mu \mathrm{g} / \mathrm{ml})$ of Nigella sativa seed extract over a period of $48 \mathrm{~h}$

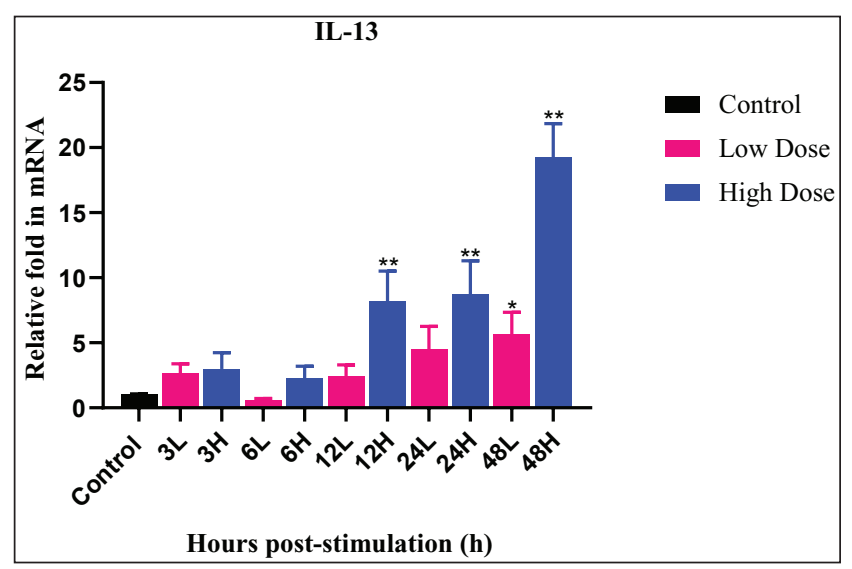

Fig. 3: Relative expression of IL-13 transcript in chicken PBMCs stimulated with Low dose $(125 \mu \mathrm{g} / \mathrm{ml})$ and High dose $(250 \mu \mathrm{g} / \mathrm{ml})$ of Nigella sativa seed extract over a period of $48 \mathrm{~h}$

Effect of Nigella sativa seed extract on Th1 cytokine gene expression in the chicken PBMCs

CD4+ Th1 cells, CD8+ T cells, NK cells, macrophages and DCs produce IFN- $\gamma$ and regulate it in an autocrine fashion (Schroder et al., 2004; Frucht et al., 2001; CarvalhoPinto et al., 2002). IFN- $\gamma$ possess the antiviral activity by inducing CD8+ T cells, NK cells and interferon inducible genes (Romagnani, 1997; Samuel, 2001) and plays an essential role in innate as well as adaptive immunity (Samuel, 2001). In our current study, the high dose of Nigella sativa up-regulated IFN- $\gamma$ transcripts significantly at $12(\mathrm{P} \leq 0.05), 24$ and $48 \mathrm{~h}(\mathrm{P} \leq 0.01)$ post-stimulation in the chicken PBMCs, which were to the tune of 11.5359 $\pm 2.11920,11.7301 \pm 3.64259$ and $18.2217 \pm 2.77$ folds, respectively (Fig. 4).

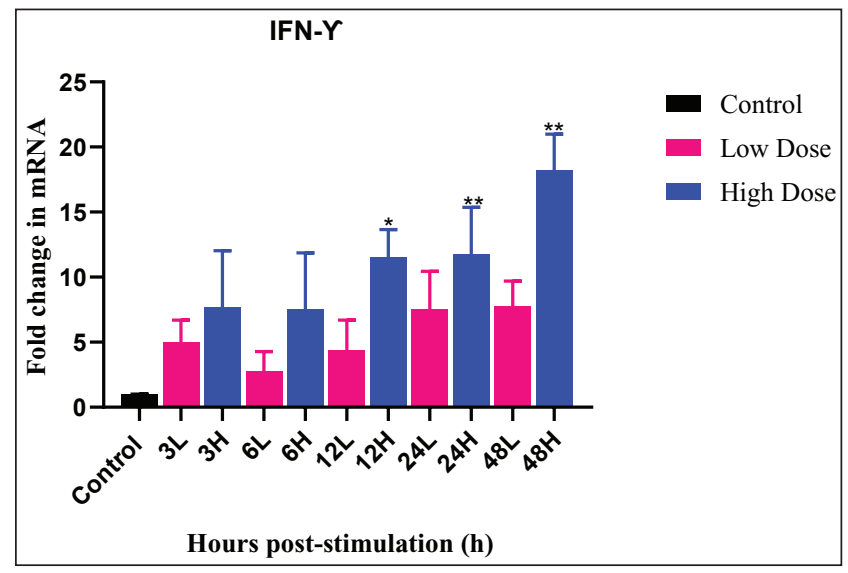

Fig. 4: Relative expression of IFN- $\Upsilon$ transcript in chicken PBMCs stimulated with Low dose $(125 \mu \mathrm{g} / \mathrm{ml})$ and High dose $(250 \mu \mathrm{g} / \mathrm{ml})$ of Nigella sativa seed extract over a period of $48 \mathrm{~h}$

The high dose of Nigella sativa seed extract significantly $(\mathrm{P} \leq 0.01)$ up-regulated the IL-12 transcripts in the chicken PBMCs at $6,12,24$ and $48 \mathrm{~h}$ post-stimulation with a peak level of $37.47 \pm 5.22$ folds at $48 \mathrm{~h}$ time interval (Fig. 5).

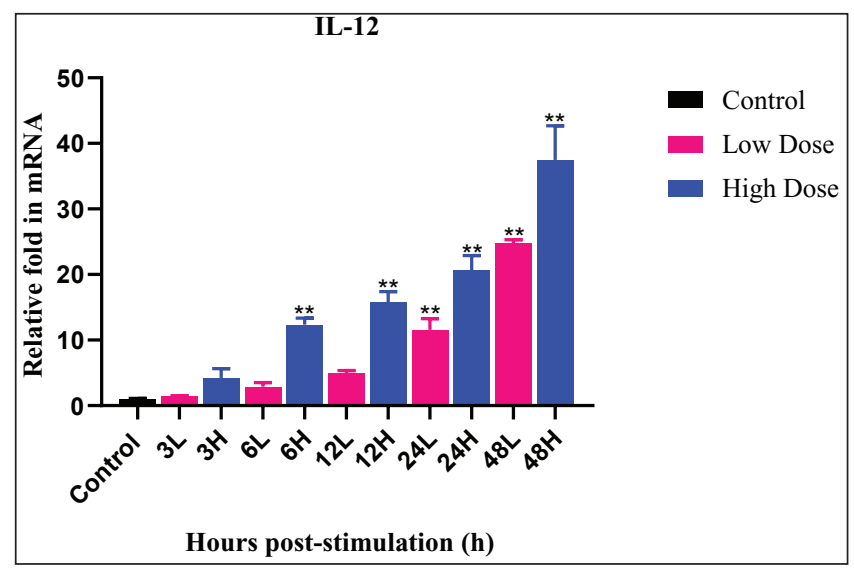

Fig. 5: Relative expression of IL-12 transcript in chicken PBMCs stimulated with Low dose $(125 \mu \mathrm{g} / \mathrm{ml})$ and High dose $(250 \mu \mathrm{g} / \mathrm{ml})$ of Nigella sativa seed extract over a period of $48 \mathrm{~h}$

Further, the low dose of Nigella sativa seed extract significantly $(\mathrm{P} \leq 0.01)$ up-regulated the IL-12 transcripts in the chicken PBMCs at 24 and 48 h post-stimulation only. The present findings suggested the potential of Nigella sativa seed extract in inducing the Th1 cytokine responses 
in the chicken PBMCs, which can be further tested as an adjuvant with any antigen or vaccine in chickens for the possible enhancement of cell mediated immune responses.

Effect of Nigella sativa seed extract on Antiinflammatory and $\mathrm{Th} 2$ cytokine gene expression in the chicken PBMCs

The high dose of Nigella sativa seed extract induced both IL-4 and IL-13 transcripts in the chicken PBMCs at 12, 24 and $48 \mathrm{~h}$ post-stimulation and the low dose was able to induce them only at $48 \mathrm{~h}$ post-stimulation. The level of IL-4 expression was $9.01 \pm 2.88,11.00 \pm 3.28$ and $17.88 \pm$ 2.93 folds at 12,24 and $48 \mathrm{~h}$ post-stimulation, respectively (Fig. 6).

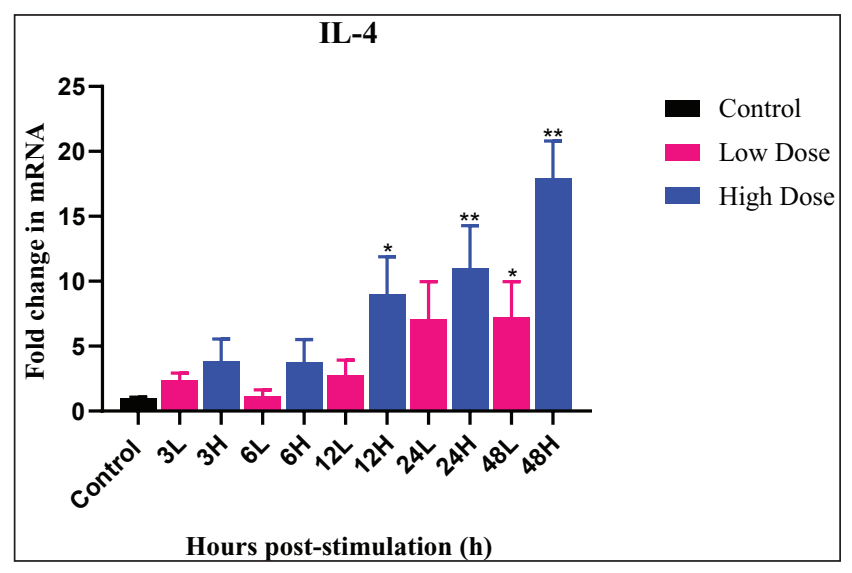

Fig. 6: Relative expression of IL-4 transcript in chicken PBMCs stimulated with Low dose $(125 \mu \mathrm{g} / \mathrm{ml})$ and High dose $(250 \mu \mathrm{g} /$ $\mathrm{ml}$ ) of Nigella sativa seed extract over a period of $48 \mathrm{~h}$

While the level of IL-13 transcripts was $8.1994 \pm 2.31790$, $8.7327 \pm 2.57686$ and $19.24 \pm 2.6$ folds at 12,24 and 48 $\mathrm{h}$ post-stimulation, respectively (Fig. 3). The high dose of Nigella sativa seed extract also induced significantly $(\mathrm{P} \leq 0.01)$ higher level of IL-10 transcripts in the chicken PBMCs, which were $8.06 \pm 2.13 ; 7.45 \pm 2.52$ and $11.57 \pm$ 2.23 folds, respectively at 12,24 and $48 \mathrm{~h}$ post-stimulation (Fig. 7). Previous studies have revealed out the antiinflammatory potential of Nigella sativa. IL-13 and IL-4 are predominantly produced by Th2 cells and also by CD8+ T cells, mast cells, eosinophils and basophils. Majdalawieh et al., 2010 tested Nigella sativa aqueous extract on splenocytes and finds that it was potentially effective and significantly enhanced the secretion of IL-4 and IL-10 which corroborated the present findings.
Further, the results of the present study indicated the potential of Nigella sativa seed extract to induce Th2 cytokine responses in the chicken PBMCs, which could possibly help for further enhancement of antigen specific antibody responses in the chicken when used with any antigen or vaccine.

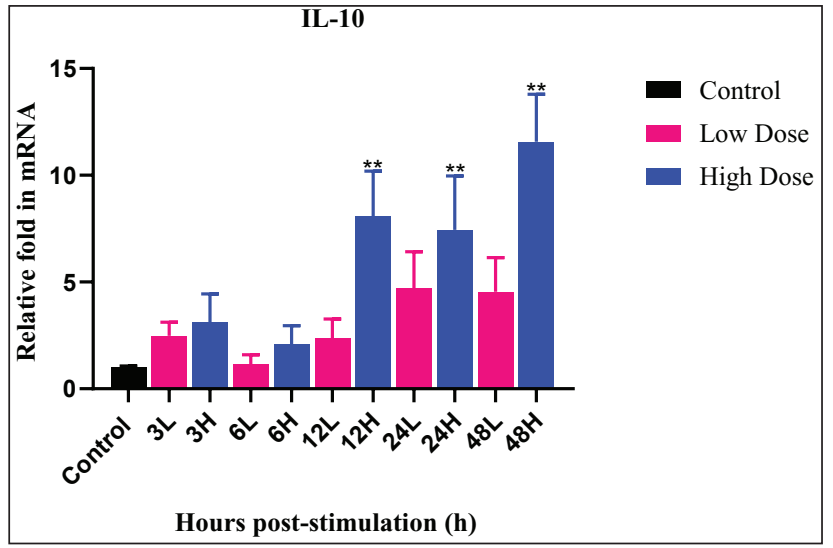

Fig. 7: Relative expression of IL-10 transcript in chicken PBMCs stimulated with Low dose $(125 \mu \mathrm{g} / \mathrm{ml})$ and High dose $(250 \mu \mathrm{g} / \mathrm{ml})$ of Nigella sativa seed extract over a period of $48 \mathrm{~h}$

\section{CONCLUSION}

In conclusion, Nigella sativa methanolic extract induced the expression of IL- $1 \beta$, IFN- $\beta$, IFN- $\gamma$, IL-4, IL-10, IL-13, and IL-12 transcripts in the chicken PBMCs. The results of the present study indicated the ability of the Nigella sativa methanolic extract to induce pro-inflammatory, antiviral, Th1 and Th2 cytokine responses. Hence, the Nigella sativa methanolic extract can be tried as an adjuvant with any vaccine or antigen in the chicken.

\section{ACKNOWLEDGEMENTS}

The authors acknowledge the help and necessary facilities provided by The Director, ICAR - Indian Veterinary Research Institute, Izatnagar-243 122, Bareilly-Uttar Pradesh (India) for this investigation.

\section{REFERENCES}

Ahmad, A., Husain, A., Mujeeb, M., Khan, S.A., Najmi, A.K., Siddique, N.A., Damanhouri, Z.A. and Anwar, F. 2013. A review on therapeutic potential of Nigella sativa: A miracle herb. Asian Pac. J. Trop. Biomed., 3(5): 337-352. 
Akinwumi, K.A., Jubril, A.J., Olaniyan, O.O. and Umar, Y.Y. 2020. Ethanol extract of Nigella sativa has antioxidant and ameliorative effect against nickel chloride-induced hepatorenal injury in rats. Clin. Phytoscience., 6(1): 1-12.

Al-Sheddi, E.S., Farshori, N.N., Al-Oqail, M.M., Musarrat, J., Al-Khedhairy, A.A. and Siddiqui, M.A. 2014. Cytotoxicity of Nigella sativa seed oil and extract against human lung cancer cell line. Asian Pac J Cancer Prev., 15(2): 983-987.

Barlianto, W., Rachmawati, M., Irawan, M. and Wulandari, D. 2017. Effects of Nigella sativa oil on Th1/Th2, cytokine balance, and improvement of asthma control in children. Paediatr Indones., 57(5): 223-8.

Berzi, A., Varga, N., Sattin, S., Antonazzo, P., Biasin, M., Cetin, I.,Trabattoni, D., Bernardi, A., Clerici, M. 2014. Pseudomannosylated DC-SIGN ligands as potential adjuvants for HIV vaccines. Viruses, 6: 391-403.

Boeglin, E., Smulski, C.R., Brun, S., Milosevic, S., Schneider, P., Fournel, S. 2011. Toll-like receptor agonists synergize with CD40L to induce either proliferation or plasma cell differentiation of mouse B cells. PLoS One., 6: e25542.

Boskabady, M.H., Keyhanmanesh, R., Khameneh, S., Doostdar, Y. and Khakzad, M.R. 2011. Potential immunomodulation effect of the extract of Nigella sativa on ovalbumin sensitized guinea pigs. J. Zhejiang Univ. Sci. B., 12(3): 201-209.

Bukar, M.A., Ishaya, H.B., Dibal, N.I. and Attah, M.O.O. 2017. Gastroprotective effect of Nigella sativa seed on ethanolinduced gastric ulcer in rats. Libyan J Med Sci., 1(3): 63.

Campling, B.G., Pym, J., Baker, H.M., Cole, S.P.C. and Lam, Y.M. 1991. Chemosensitivity testing of small cell lung cancer using the MTT assay. Br. J. Cancer, 63(1): 75-83.

Carvalho-Pinto, C.E., García, M.I., Mellado, M., RodríguezFrade, J.M., Martín-Caballero, J., Flores, J., Martínez-A, C. and Balomenos, D. 2002. Autocrine production of IFN- $\gamma$ by macrophages controls their recruitment to kidney and the development of glomerulonephritis in MRL/lpr mice. $J$. Immunol., 169: 1058-1067.

Cole, S.P.C. 1986. Rapid chemosensitivity testing of human lung tumor cells using the MTT assay. Cancer Chemother. Pharmacol., 17(3): 259-263.

Dilshad, A., Abulkhair, O., Nemenqani, D. and Tamimi, W. 2012. Antiproliferative properties of methanolic extract of Nigella sativa against the MDA-MB-231 cancer cell line. Asian Pac J. Cancer Prev., 13(11): 5839-5842.

Frucht, D.M., Fukao, T., Bogdan, C., Schindler, H., O’Shea, J.J., Koyasu, S. 2001. IFN- $\gamma$ production by antigen-presenting cells: mechanisms emerge. Trends Immunol., 22: 556-560.

Gholamnezhad, Z., Rafatpanah, H., Sadeghnia, H.R. and Boskabady, M.H. 2015. Immunomodulatory and cytotoxic effects of Nigella sativa and thymoquinone on rat splenocytes. Food Chem. Toxicol., 86: 72-80.

Heggen, C.L., Qureshi, M.A., Edens, F.W. and Barnes, H.J., 2000. Alterations in macrophage-produced cytokines and nitrite associated with poult enteritis and mortality syndrome. Avian Dis., 44: 59-65.

Huang, H., Jiao, X., Xu, Y., Han, Q., Jiao, W., Liu, Y., Li, S. and Teng, X. 2019. Dietary selenium supplementation alleviates immune toxicity in the hearts of chickens with lead-added drinking water. Avian Pathol., 48(3): 230-237.

Hussain, D.A. and Hussain, M.M. 2016. Nigella sativa (black seed) is an effective herbal remedy for every disease except death-a Prophetic statement which modern scientists confirm unanimously: a review. Adv. Med. Plant. Res., 4(2): 27-57.

Kuo, S.M., Chen, C.J., Chang, S.C., Liu, T.J., Chen, Y.H., Huang, S.Y. and Shih, S.R. 2017. Inhibition of avian influenza A virus replication in human cells by host restriction factor TUFM is correlated with autophagy. MBio., 8(3).

Liu, H., Zhang, M., Han, H., Yuan, J. and Li, Z. 2010. Comparison of the expression of cytokine genes in the bursal tissues of the chickens following challenge with infectious bursal disease viruses of varying virulence. Virol. J., 7(1): 1-9.

Majdalawieh, A.F., Hmaidan, R. and Carr, R.I. 2010. Nigella sativa modulates splenocyte proliferation, Th1/Th2 cytokine profile, macrophage function and $\mathrm{NK}$ anti-tumor activity. $J$. Ethnopharmacology., 131(2): 268-275.

Okeola, V.O., Adaramoye, O.A., Nneji, C.M., Falade, C.O., Farombi, E.O. and Ademowo, O.G. 2011. Antimalarial and antioxidant activities of methanolic extract of Nigella sativa seeds (black cumin) in mice infected with Plasmodium yoelli nigeriensis. Parasitol. Res., 108(6): 1507-1512.

Pfaffl, M.W. 2001. A new mathematical model for relative quantification in real-time RT-PCR. Nucleic. Acids. Res., 29: e45-e45.

Rahman, M.M., Eo, S.K. 2012. Prospects and challenges of using chicken cytokines in disease prevention. Vaccine., 30: 7165-7173.

Ramakrishnan, S., Annamalai, A., Sachan, S., Kumar, A., Sharma, B.K., Govindaraj, E., Chellappa, M.M., Dey, S. and Krishnaswamy, N. 2015. Synergy of lipopolysaccharide and resiquimod on type I interferon, pro-inflammatory cytokine, Th1 and Th2 response in chicken peripheral blood mononuclear cells. Mol. Immunol., 64(1): 177-182.

Romagnani,S. 1997. The Th1/Th2 paradigm. Immunol. Today, 18: 263-266.

Salman, M.T., Khan, R.A. and Shukla, I. 2016. Antibacterial activity of Nigella sativa Linn. Seeds against multiple antibiotics resistant clinical strains of Staphylococcus aureus. Int. Arch. BioMed. Clin. Res., 2: 96-99. 
Samuel, C.E. 2001. Antiviral actions of interferons.Clin. Microbiol.Rev., 14:778-809.

Schroder, K., Hertzog, P.J., Ravasi., Hume, D.A., 2004. Interferon- $\gamma$ : an overview of signals, mechanisms and functions. J. Leukoc. Biol., 75: 63-189.

Seo, Y.J., Hahm, B. 2010. Type I interferon modulates the battle of host immune system against viruses. Adv. Appl. Microbiol., 73:83-101.

Swamy, S.M.K. and Tan, B.K.H. 2000. Cytotoxic and immunopotentiating effects of ethanolic extract of Nigella sativa L. seeds. J. Ethnopharmacology., 70(1): 1-7.
Zainiyah, H., Noviani, N.W. and Hipni, R. 2018. The positive effect of black cumin ethanol extract (Nigella sativa) on decreasing serum TNF- $\alpha$ levels and interleukin- 8 levels in mice model of preeclampsia. Biomed. Res., 29: 18-1097.

Zhang, B., Gan, L., Shahid, M.S., Lv, Z., Fan, H., Liu, D. and Guo, Y. 2019. In vivo and in vitro protective effect of arginine against intestinal inflammatory response induced by Clostridium perfringens in broiler chickens. J. Anim. Sci Biotechno., 10(1): 1-14. 